\title{
Kretanje cijena nafte i prihodi državnog proračuna
}

\author{
PETAR SOPEK \\ IVAN ŠKOC
}

Cijene sirove nafte na svjetskom tržištu od druge polovice 20I4. zabilježile su značajan pad, što je dovelo do pada maloprodajnih cijena (MPC) benzinskih i dizelskih goriva i na hrvatskom tržištu. Sredinom veljače 20I5. cijena Eurosupera 95 iznosila je 9,32 kune, a Eurodiesela 8,84 kune. Cijene goriva od tada lagano rastu, prije svega zbog porasta cijene sirove nafte i tečaja dolara, pa prosječna cijena benzina 8. ožujka iznosi 9,56 kn/l, a dizela 9,oI kn/l. U odnosu na prosjek MPC-a iz 20I4., cijene iz ožujka 20I5. ipak su u prosjeku niže za Io-ak posto. Provedena analiza pokazuje da niže cijene goriva dugoročno ne bi trebale imati negativan učinak na prihode državnog proračuna zbog pozitivne cjenovne elastičnosti potražnje, učinka redistribucije prihoda od PDV-a te nižih vlastitih rashoda javnoga sektora.

\section{KRETANJE GIJENA SIROVE NAFTE}

Sirova nafta je jedna od najznačajnijih svjetskih sirovina kojom se svakodnevno trguje na svjetskom tržištu; klasificira se prema raznim svojstvima, uglavnom prema geografskom podrijetlu, specifičnoj gustoći te količini sumpora. U trgovanju na svjetskom tržištu koriste se uglavnom neki standardizirani tipovi nafte koji služe kao mjerilo (engl. marker), kako bi se lakše referencirale cijene. Za europsko tržište mjerilo je Brent (Dated Brent) - mješavina I5 tipova sirovih nafti iz Sjevernog mora ${ }^{\mathrm{I}}$. Cijene sirove nafte dobivene iz Europe, Bliskog istoka i Rusije vezane su uz Brent.

Prema povijesnim podacima Energy Information Administration (EIA, 20I5a), prosječna cijena Brenta je 20I3. iznosila približno Io9 USD po barelu. Slična razina cijene zadržala se i na prijelazu u 20I4., potpomognuta razvojem libijske, ukrajinske te krize na Bliskom istoku. Kako su militanti ISIS-a napredovali prema Bagdadu, ukrajinska kriza nije jenjavala, i uz smanjenu ponudu iz Libije, u lipnju 2014. cijena barela Brenta premašila je II5 USD. Tijekom srpnja 20I4. situacija u Iraku se počela smirivati, a Libija je ponovno otvorila dvije velike izvozne luke (Es Sidra i Ras Lanuf), pa je cijena barela sirove nafte počela postepeno padati. U drugoj polovici 20I4. na cijenu nafte sve snažnije je počeo utjecati i procvat

\footnotetext{
${ }^{\mathrm{I}}$ Dated Brent je mjerilo procjene cijene koje se koristi pri fizičkom trgovanju teretima sirove nafte u Sjevernom moru, vezano uz određene datume isporuke te su prilikom fizičkog trgovanja sirovom naftom ugovorene cijene najčešće vezane uz ovaj marker. Stoga je Dated Brent korišten kao mjerilo cijene sirove nafte na određeni dan. Izvorno, Brent je akronim (pokrata) naziva glavnih naftnih bušotina u Sjevernom moru.
} 
proizvodnje sirove nafte iz škriljca u SAD-u. Brent je u rujnu 20I4. pao ispod Ioo USD za barel, što se nije dogodilo sve od travnja 2OI3. Prema podacima EIA (2OI5b), u listopadu 20I4. proizvodnja nafte u SAD-u iznosila je preko devet milijuna barela dnevno, čime je gotovo dosegnuta rekordna razina proizvodnje iz 1970. U Europi i Aziji, a posebno zbog usporavanja rasta gospodarstava Kine i Njemačke, padala je potražnja za sirovom naftom. Očekivalo se da će članice Organizacije zemalja izvoznica nafte (OPEC) smanjenjem proizvodnje zaustaviti daljnji pad cijena sirove nafte, no neke članice - prvenstveno Saudijska Arabija kao najveći proizvođač OPEC-a - to nisu željele. Nakon sastanka OPEC-a u Beču krajem studenoga 20I4., na kojem je službeno odlučeno da se neće smanjivati proizvodnja, cijene sirove nafte nastavile su sa silaznim trendom (Vox, 20I4). U prosincu 20I4. cijena Brenta pala je ispod 6o USD za barel, a trend pada se nastavio i početkom 2015. U siječnju 2015. barel nafte pao je ispod 5o USD, poduprt slabim prognozama o rastu najvećih svjetskih gospodarstava te obilnom ponudom. S vremenom je, ipak, značajan pad cijena utjecao na proizvodnju. Podatak o 23\%-tnom padu broja aktivnih bušotina u SAD-u u odnosu na siječanj, smatra se jednim od glavnih uzroka ponovnog rasta cijena sirove nafte početkom veljače. ${ }^{2}$ Izjava kuvajtskoga ministra da će niža razina opskrbe poduprijeti cijene u drugoj polovini godine, te eskalacija sukoba s islamskim militantima i napad na naftovod u Libiji uzrokovali su rast cijena sirove nafte prema razini od oko 6o USD po barelu, još jednom potvrđujući nepredvidivost naftnog tržišta (Poslovni dnevnik, 20I5). Ipak i ta je cijena gotovo dvostruko niža u odnosu na prethodnu godinu.

Implikacije ovako značajnog pada cijena sirove nafte su dvojake. Zemlje čiji je BDP i proračunski prihod usko vezan uz izvoz nafte i plina - poput Rusije, Irana ili Venezuele - suočene su sa značajno manjim proračunskim prihodima. S druge strane, zemlje koje su veliki uvoznici nafte - poput Kine i zemalja EU-a trebale bi imati značajno manje izdatke za uvoz ovoga energenta. Daljnji pad cijena nafte mogao bi utjecati i na smanjenje proizvodnje u SAD-u i Kanadi. Budući da je cijena proizvodnje sirove nafte iz škriljca i pijeska skuplja od konvencionalnih izvora, moglo bi se dogoditi da takva nalazišta postanu neprofitabilna, no granična cijena profitabilnosti još uvijek nije jasno utvrđena. Prema podacima švicarske banke UBS, ovako niske cijene pogoduju mnogima, a među 54 zemlje najveću bi korist mogle imati Filipini, Turska i Hrvatska (RH). Predviđa se da bi hrvatski BDP zbog niske cijene nafte mogao biti za o,4\% veći (Businessinsider, 20I4). Istraživanje koje je proveo Oxford Economics pokazalo je da bi u slučaju pada i zadržavanja cijene sirove nafte na razinu od 4O USD po barelu tijekom cijele 20I5., pozitivan učinak na rast BDP-a RH bio još i veći - oko o,8\% (Fortune, 2015).

Cilj je ovoga rada pojasniti utjecaj kretanja cijene sirove nafte na prihode državnog proračuna - od trošarina i PDV-a.

\section{OD GIJENA SIROVE NAFTE DO MPG-A GORIVA}

Cijene sirove nafte i naftnih derivata globalno su pod utjecajem raznih ekonomskih, političkih, tehnoloških, sezonskih, ali i špekulativnih faktora. Premda porast cijena sirove nafte na svjetskom tržištu najčešće automatski potiče i povećanje cijene naftnih derivata, to ne mora baš uvijek biti tako. Višak ponude nad potražnjom sirove nafte na svjetskom tržištu dovodi do pada cijene te sirovine. Međutim, ako se istovremeno pojavio neki tehnički problem u radu rafinerije koja sirovu naftu prerađuje u motorna goriva, poslovanje rafinerije na neko vrijeme može biti obustavljeno. U tom slučaju cijena goriva može porasti zbog nedostatne ponude motornih goriva na lokalnom tržištu, usprkos istodobnom padu cijena sirove nafte koja se koristi kao sirovina u rafineriji. MPC goriva ovise i o transportnim troškovima, pa u slučaju povećanja troškova transporta cijena naftnih derivata raste neovisno o kretanju cijene sirove nafte na tržištu (npr. može se raditi i o porastu cijene osiguranja transporta).

Budući da je proizvodnja sirove nafte iz domaćih izvora nedostatna, RH najvećim dijelom uvozi sirovu naftu kako bi zadovoljila rafinerijsku potražnju, ali uvozi i određenu količinu naftnih derivata, ponajviše

\footnotetext{
${ }^{2}$ Broj aktivnih bušotina u SAD-u prati se i ažurira tjedno, a podaci su dostupni na web stranici. Jednom mjesečno objavljuju se i
} internacionalni podaci o broju aktivnih bušotina. 
dizelskog goriva 3 . Budući da se sirova nafta na tržištu kupuje u američkim dolarima, cijena indirektno ovisi i o odnosu tečaja kune i američkog dolara.

Strukturno gledajući, visinu MPG-a naftnih derivata kod proizvodnje općenito određuje cijena sirove nafte, ali i marža, trošarine i PDV. Marža obuhvaća troškove transporta i osiguranja, trošak prerade sirove nafte, te troškove skladištenja i distribucije proizvoda sve do prodaje krajnjem korisniku.

U Hrvatskoj je MPC naftnih derivata (motornih benzina, dizelskih goriva te plinskih i loživih ulja) sve do veljače 2OI4. i donošenja novog Zakona o tržištu nafte i naftnih derivata (NN 19/I4.) regulirala država koja je određivala maksimalni MPC za tzv. obračunsko razdoblje. Bila je propisana i maksimalna dopuštena promjena maksimalnog MPC-a pojedinog naftnog derivata na dan obračuna u odnosu na prethodno obračunsko razdoblje, čime je ograničena fluktuacija cijene između obračunskih razdoblja ${ }^{4}$. Unutar obračunskog razdoblja, energetski subjekti mogli su prodavati naftne derivate po cijenama koje nisu smjele biti više od maksimalnih.

Način izračuna maksimalnog MPC-a naftnih derivata za obračunsko razdoblje bio je propisan Pravilnikom, a formula za izračun se bazirala na sljedećim komponentama:

- osnova za obračun prodajnih cijena;

- ovisni troškovi (troškovi skladištenja i manipulacije);

- troškovi prometa na veliko i malo (marža);

- trošarine;

- PDV.

Osnovu za obračun prodajnih cijena naftnog derivata za obračunsko razdoblje činila je prosječna cijena naftnog derivata na tržištu Mediterana (srednja vrijednost burzovnih kotacija Mediterranean Cargoes CIF Med Genova/Lavera) u obračunskom razdoblju koje prethodi novom obračunskom razdoblju, pretvorena $\mathrm{u}$ kune prema tečaju američkog dolara u istom razdoblju5. Na obračunsku osnovu dodali bi se ovisni troškovi i premija energetskog subjekta (marža) u fiksnom iznosu propisanom pravilnikom. Tim se izračunom dobiva cijena naftnog derivata bez davanja državi. Da bi se došlo do MPC-a, potrebno je dodati fiksni iznos trošarine za pojedini naftni derivat i na sve to obračunati PDV.

Premda se sama formula za izračun maksimalnih cijena mijenjala izmjenama Pravilnika, u izračunu MPC-a derivata u obračunsku se osnovu uvijek uzimala cijena derivata na Mediteranu, a ne cijena sirove nafte. Grafikon I prikazuje kretanje maksimalnih MPC-a benzina Euro 95 BS i Eurodiesela BS u razdoblju od 2OIO.-I4. Realno je pretpostaviti da je stvarni MPC bio u prosjeku gotovo jednak maksimalnom MPC-u u vrijeme dok je bio reguliran pravilnikom (20. veljače 20I4.), a od trenutka slobodnog formiranja cijene korištene su prosječne dnevne cijene naftnih derivata prema dostupnim podacima s interneta ${ }^{6}$.

\footnotetext{
${ }^{3}$ Prema podacima INA-e, od 4 milijuna tona sirove nafte koliko se godišnje preradi, nešto iznad 20\% je domaća sirovina, a ostalo je uvoz (Vorša, 2OI2).

${ }^{4} \mathrm{Npr}$. promjene MPC-a naftnih derivata nisu mogle biti veće od $3 \%$ na više i $6 \%$ na niže u odnosu na cijenu iz prethodnog obračunskog razdoblja (Pravilnik o utvrđivanju najviših MPC-a naftnih derivata, NN 145/I2.).

${ }^{5}$ Sve do stupanja na snagu Pravilnika o utvrđivanju cijena naftnih derivata (NN 46/Io.) u travnju 2Oıo., koristio se prosjek prodajnog tečaja HNB-a, nakon kojeg se cijena računa prema srednjem tečaju HNB-a.

${ }^{6} \mathrm{Na}$ www.cijenegoriva.info se svakodnevno objavljuju cijene goriva na benzinskim postajama diljem RH koje variraju na pojedinačnim postajama, ovisno o cjenovnoj politici kompanije.
} 


\section{Grafikon I.}

Kretanje maksimalne cijene dizela i benzina u usporedbi s cijenom sirove nafte Dated Brent u razdoblju 2010. do 20I4., u kunama po litri goriva

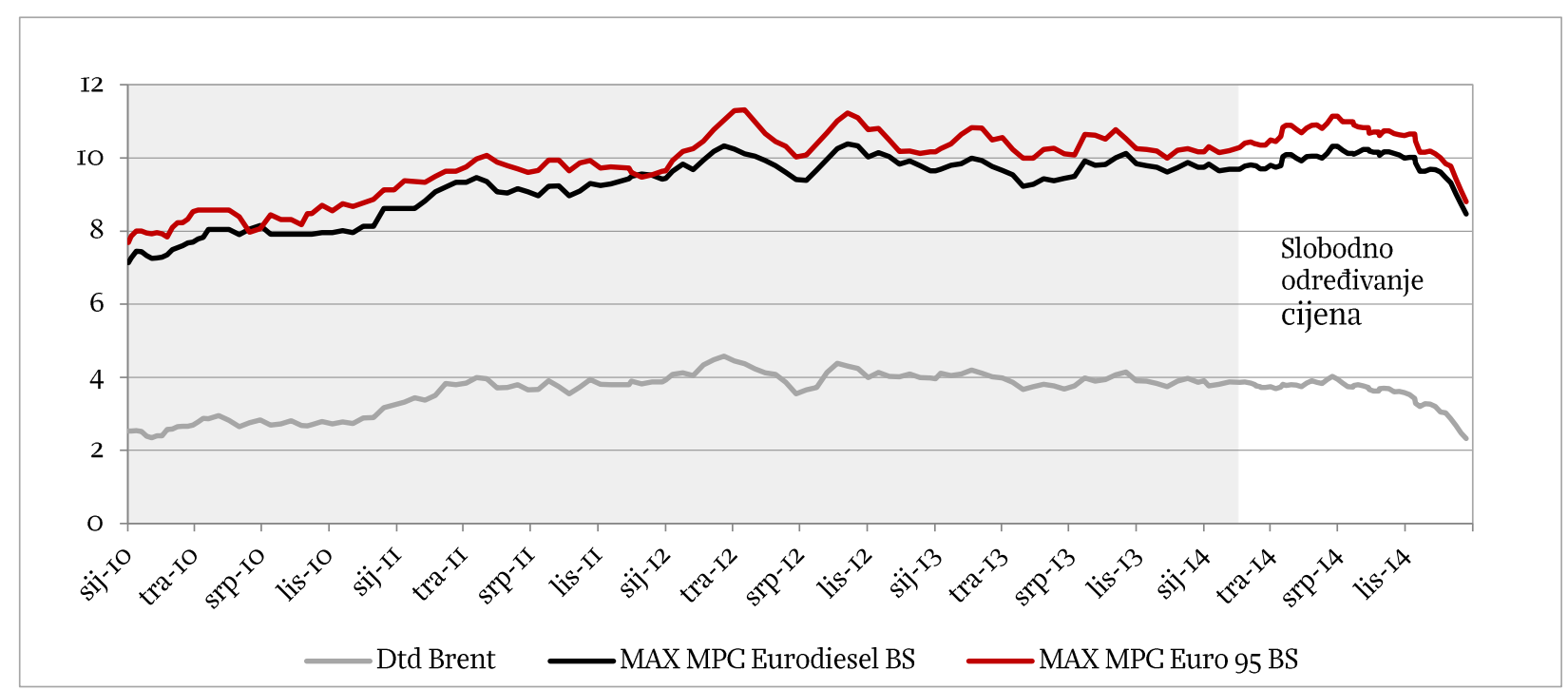

Izvor: Ministarstvo gospodarstva(2OI5), EIA(2OI5a), prilagodba autora

Prosječni maksimalni MPC dizela u promatranom razdoblju iznosio je 9,07 kn/l, a benzina 9,65 kn/17. Kretanje cijena naftnih derivata u osnovi je pratilo kretanje cijena Brenta, budući da je cijena derivata usko vezana uz cijenu sirove nafte. Najviše razine derivata i sirove nafte bile su u travnju 20I2. Dok je prosječna cijena sirove nafte iznosila oko I2O USD po barelu (preračunato 4,3 kn/l), prosječna cijena benzina bila je 9,93 kn te dizela 9,38 kn. Nešto niža cijena sirove nafte bila je u lipnju 20I4. (3,93 kn/l). Benzin je tada koštao 9,93 kn/l, a dizel 9,38 kn/l.

Kao što je već prije rečeno, u MPC-u benzina i dizela sadržane su dvije komponente prihoda državnog proračuna - trošarina i $\mathrm{PDV}^{8}$. Trošarina je specijalan oblik poreza koji se na benzinska i dizelska goriva obračunava $u$ apsolutnom iznosu po jedinici mjere proizvoda (I.Ooo litara pri osnovnim uvjetima temperature energenta od $+15{ }^{\circ} \mathrm{C}$ ). Drugim riječima, na svakih I.ooo litara plaća se fiksna cijena koja ne ovisi o MPC-u goriva. Iznos trošarine, zajedno s ostalim elementima (nabavna cijena sirovine, ovisni troškovi, marža itd.), ulazi u poreznu osnovicu za obračun PDV-a po općoj stopi od 25\%. Tablica I prikazuje kretanje trošarina na benzinska i dizelska goriva u razdoblju od 1994. do 2014.

Od I. srpnja 1994. do početka 20IO. u primjeni je bio Zakon o posebnom porezu na naftne derivate. U razdoblju od 2002.-10. apsolutni iznos trošarina se smanjivao. U 2010. RH se postupno krenula usklađivati sa zakonodavstvom EU-a, pa donosi Zakon o trošarinama koji - između ostaloga - regulira i trošarine na

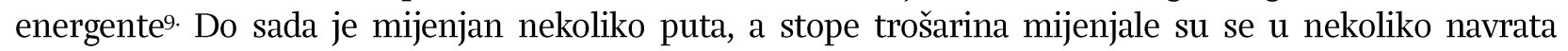
zasebnim uredbama ${ }^{\mathrm{IO}}$. U siječnju 2010. trošarine su značajno porasle; za $72 \%$ na benzinska i $120 \%$ za dizelska goriva. Nakon manjeg pada u 20II., trošarine postupno rastu, što je djelomice posljedica usklađivanja s minimalnim stopama trošarina EU-a (primjerice kod dizelskog goriva), ali se ipak najvećim dijelom radilo o fiskalnim motivima, tj. povećanju proračunskih prihoda. Zadnje povećanje trošarina bilo

\footnotetext{
7 Pod pojmovima"cijena dizela i benzina" dalje u tekstu misli se na cijene derivata Eurodiesel BS i Eurosuper 95 BS.

${ }^{8}$ Povrh samih trošarina, do kraja 20I2. cijena goriva sadržavalaje i naknadu za financiranje rada Hrvatske agencije za obvezne zalihe nafte i naftnih derivata (HANDA) i obveznih zaliha nafte i naftnih derivata, a iznos se za svaku godinu zasebno definirao odlukama. Od I. siječnja 2OI3. Zakonom o izmjenama Zakona o tržištu nafte i naftnih derivata (NN I44/I2.), rad Agencije financira se iz državnog proračuna.

9 Zakon o trošarinama regulira tzv. harmonizirane trošarine, tj. trošarine na skupinu proizvoda (alkohol i alkoholna pića, duhanske proizvode i energente) za koje je zakonski okvir donesen I. siječnja 1993. prilikom uspostavljanja Zajedničkog tržišta EU-a.

ro Osim povećanja stopa trošarina na motorna goriva, novim Zakonom o trošarinama iz 20I3. uvedeno je i oporezivanje prirodnog plina, ugljena, koksai električne energije.
} 
je u travnju 20I4. kada je trošarina za motorne benzine povećana s 3,46 kn/l na 3,66 kn/l, a za dizelska goriva s 2,66 kn/l na 2,86 kn/l. Ovi iznosi trošarina su viši u odnosu na minimalne trošarine koje propisuje $\mathrm{EU}$, a koje iznose $2,74 \mathrm{kn} / 1$ za benzinska te $2,52 \mathrm{kn} / \mathrm{l}$ za dizelska goriva ${ }^{\text {II }}$.

Tablica I.

Kretanje trošarina na benzinska i dizelska goriva u razdoblju od I994. do 20I4., u kunama po litri goriva

\begin{tabular}{|c|c|c|c|}
\hline $\begin{array}{l}\text { Početak } \\
\text { primjene }\end{array}$ & $\begin{array}{l}\text { Bezolovni } \\
\text { benzin }\end{array}$ & $\begin{array}{l}\text { Dizelska } \\
\text { goriva }\end{array}$ & Izvor \\
\hline I. srpnja I994. & $\mathrm{I}, 6 \mathrm{O}$ & $\mathrm{I}, 4 \mathrm{O}$ & Zakon o posebnom porezu na naftne derivate (NN 5I/94.) \\
\hline I. srpnja I999. & $\mathrm{I}, 8 \mathrm{O}$ & $\mathrm{I}, 60$ & $\begin{array}{l}\text { Zakon o izmjenama i dopunama Zakona o posebnom porezu na naftne } \\
\text { derivate (NN 67/99.) }\end{array}$ \\
\hline I. srpnja 2000. & 3,00 & 2,IO & Zakon o posebnom porezu na naftne derivate (NN 55/oo.) \\
\hline listopad 2000. & 2,40 & $\mathrm{I}, 5 \mathrm{O}$ & $\begin{array}{l}\text { Zakon o izmjenama i dopunama Zakona o posebnom porezu na naftne } \\
\text { derivate (NN IOI/oo.) }\end{array}$ \\
\hline I. siječnja 2002. & $\mathrm{I}, 90$ & $\mathrm{I}, \mathrm{OO}$ & Zakon o izmjeni Zakona o posebnom porezu na naftne derivate (NN 27/oI.) \\
\hline I. svibnja 2007. & $\mathrm{I}, 65$ & I,OO & Uredba o visini posebnog poreza na naftne derivate (NN 44/o7.) \\
\hline I. siječnja 2010. & 2,85 & 2,20 & Zakon o trošarinama (NN 83/og.) \\
\hline I. rujna 2010. & 3,IO & 2,20 & Uredba o visini trošarine za bezolovni motorni benzin (NN IO2/IO.) \\
\hline ožujak 2OII. & 2,95 & 2,05 & Uredba o visinama trošarina na motorne benzine i plinsko ulje (NN 28/II.) \\
\hline I. siječnja 2OI3. & 3,I5I & 2,354 & $\begin{array}{l}\text { Uredba o visini trošarine na motorne benzine, plinsko ulje i kerozin } \\
\text { za pogon (NN I37/I2.) }\end{array}$ \\
\hline 2. ožujka 2013. & 3,I5 & 2,45 & Zakon o trošarinama (NN 22/13.) \\
\hline 23. srpnja 20I3. & 3,36 & 2,56 & $\begin{array}{l}\text { Uredba o visini trošarine na motorne benzine, plinsko ulje i kerozin } \\
\text { za pogon (NN 93/13.) }\end{array}$ \\
\hline 3. rujna 2013. & 3,46 & 2,66 & $\begin{array}{l}\text { Uredba o visini trošarine na motorne benzine, plinsko ulje i kerozin } \\
\text { za pogon (NN ıog/I3.) }\end{array}$ \\
\hline travanj 2014. & 3,66 & 2,86 & $\begin{array}{l}\text { Uredba o izmjeni Uredbe o visini trošarine na motorne benzine, plinsko } \\
\text { ulje i kerozin za pogon (NN 48/I4.) }\end{array}$ \\
\hline
\end{tabular}

Izvor: prilagodba autora

Dio prihoda od trošarina na naftu i naftne derivate ima jasno specificiranu namjenu. Od svake litre benzinskog ili dizelskog goriva porezni obveznici uplate točno jednu kunu za financiranje građenja i održavanja javnih cesta (Zakon o cestama, čl. 9I - NN I48/I3.), od čega 20 lipa odlazi na račun Hrvatskih autocesta d.o.o. (HAC), a 80 lipa na račun Hrvatskih cesta d.o.o. (HC). Dodatnih 20 lipa iz svake litre goriva porezni obveznici plaćaju za financiranje željezničke infrastrukture (Zakon o željeznici, čl. 2I.a - NN 94/13., I48/13.) što odlazi na račun HŽ Infrastrukture d.o.o.

Bajo i Petrušić (20I4) navode da su obveze cestovnih trgovačkih društava velike i da ih ne mogu financirati bez potpora iz državnog proračuna. Financijski rizici cestovnih poduzeća su visoki zbog visoke zaduženosti. U slučaju da prijedlog monetizacije HAC-a ne bude prihvaćen (što je vrlo izgledno s obzirom na negativnu percepciju javnosti), vrlo je izvjesno da će se financiranje HAC-a morati osigurati dodatnim povisivanjem trošarina na motorna goriva.

Ukoliko se ukupna cijena naftnih derivata u razdoblju regulacije MPC-a rastavi prema odredbama pravilnika koji su se primjenjivali prema iznosu PDV-a, trošarina i marže, dobiva se struktura prikazana na grafikonima 2 i 3 . Ostatak je suma obračunske osnove i ostalih propisanih naknada i troškova koji ovdje nisu zasebno izdvajani.

Od ukupne cijene Eurosupera koju je krajnji kupac plaćao na benzinskim crpkama u razdoblju 20I0.-I4., državna davanja (trošarine i PDV) u prosjeku su činila 48-52\% ukupne cijene. Budući da se iznos trošarine

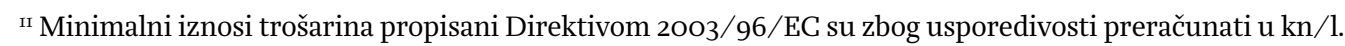


plaća po litri, neovisan je o kretanju cijene sirove nafte ili naftnih derivata na tržištu, pa se promjenom MPC-a mijenjao udio poreznih davanja u ukupnom MPC- $\mathrm{u}^{12}$.

\section{Grafikon 2.}

Struktura MPC-a benzina Eurosuper 95 BS u razdoblju 20IO. do 20I4., u kn/l

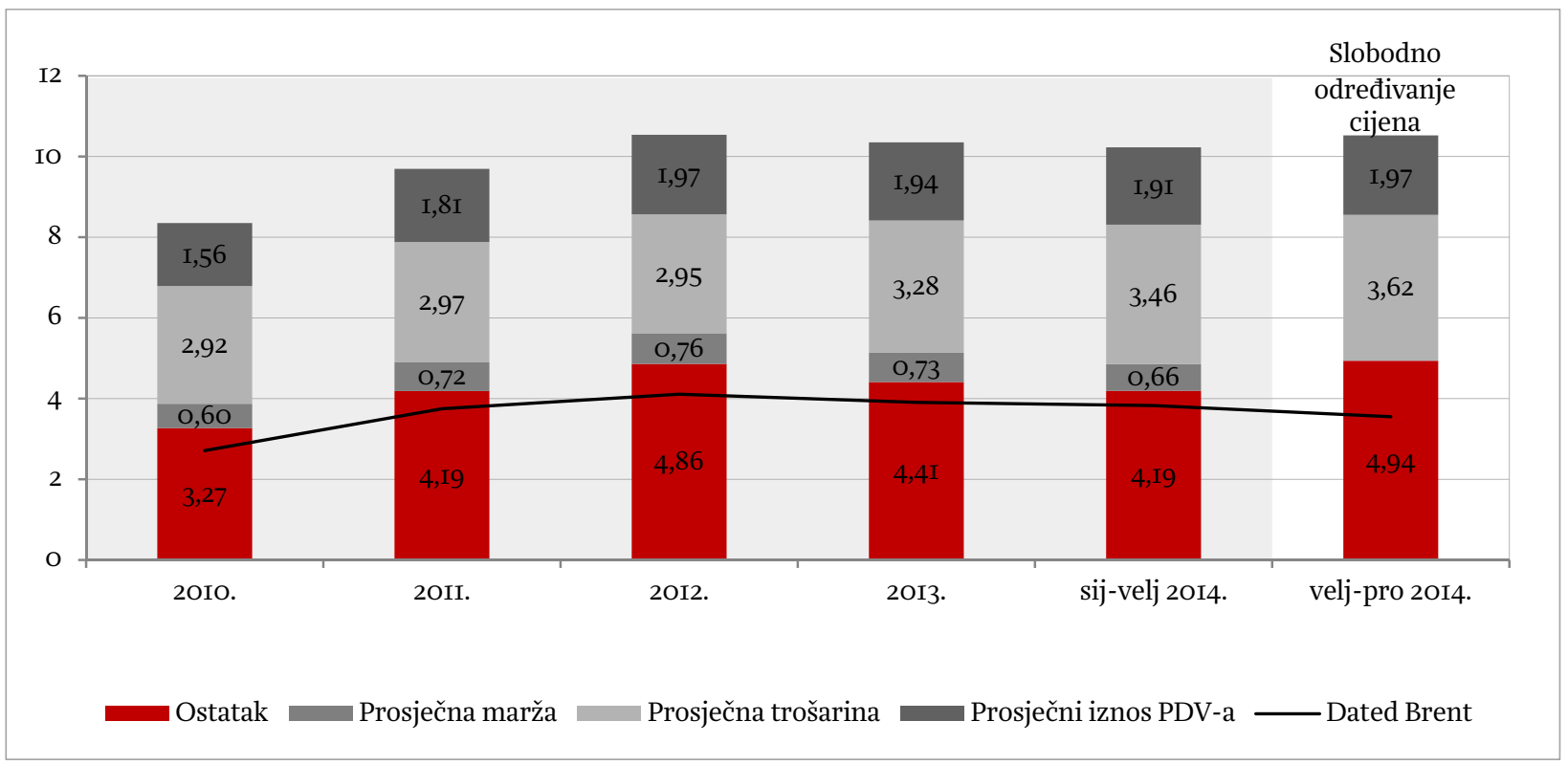

Izvor: Ministarstvo gospodarstva (20I5); EIA(20I5a); izračun autora

\section{Grafikon 3.}

Struktura MPC-a dizela Eurodiesel BS u razdoblju 20IO. do 20I4., u kn/l

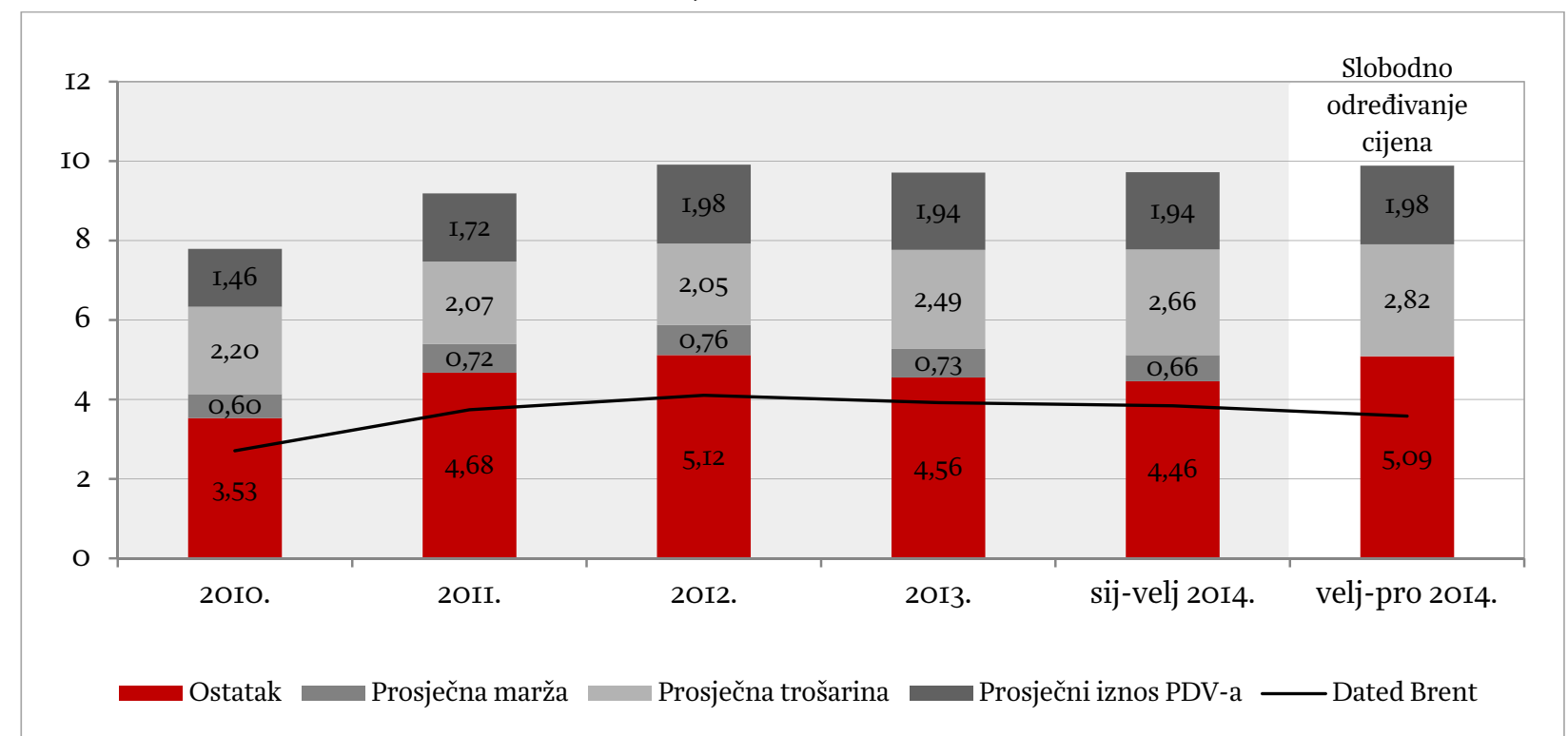

Izvor: Ministarstvo gospodarstva (20I5); EIA(2OI5a); izračun autora

Marža se u prosjeku kretala između 6o i 76 lipa po litri, što je otprilike $8 \%$ ukupne cijene. Početni iznos marže od 6olp/l je Pravilnikom o utvrđivanju najviših MPG-a naftnih derivata (NN 37/II.) od travnja 2011. povećan na 76 lp/l, budući da je iz obračunske osnove izostavljen trošak skladištenja i manipulacije. U rujnu 2013. je marža za motorne benzine i dizelska goriva smanjena na 66 lp/l, a kretanje marže nije moguće egzaktno odrediti za razdoblje slobodnog određivanja cijena

\footnotetext{
${ }^{12}$ Takva je situacija sasvim uobičajena i u svijetu. To pokazuje i analiza Newbery (2005) prema kojoj je i98I. (kad je cijena nafte bila visoka) prosječna porezna stopa na naftne derivate u europskim članicama OECD-a iznosila 41\%, a 1994. (kad je cijena nafte bila iznimno niska) je dosegla $200 \%$.
} 
Situacija je gotovo ista s dizelom. Trošarina i PDV činili su u prosjeku $44 \%$ ukupne cijene, prije svega zato što su trošarine na dizel niže od trošarina na benzine. Isti apsolutni iznos marže čini prosječno $7 \%$ ukupne cijene. Iznos trošarina do 20I4. u odnosu na 20I0. narastao je za 30\%. Propisani apsolutni iznos marže bio je isti kao i za motorne benzine te je činio prosječno 7\% ukupne cijene.

Iznos trošarine $u$ načelu se kretao $u$ suprotnom smjeru od kretanja cijene sirove nafte. Kod znatnog porasta cijene sirove nafte, a time i naftnih derivata, država je znala intervenirati snižavanjem trošarina, ali i obratno.

Novi Zakon o tržištu nafte i naftnih derivata (NN 19/I4.) propisuje da energetski subjekti mogu slobodno određivati marže koje su do tada bile fiksne i jednake za dizelska goriva i motorne benzine. Od tada je iznos marže vrlo teško odrediti. Naime, cijene derivata mogu varirati na pojedinim benzinskim crpkama, ovisno o cjenovnoj politici kompanije te se teoretski mogu mijenjati u svakom trenutku, a naftne kompanije više nisu obavezne objavljivati cijene goriva. Iznimno, radi zaštite potrošača, regulacije tržišta ili drugih opravdanih razloga, Vlada može uredbom propisati najvišu razinu MPC-a za pojedine naftne derivate, za neprekinuto razdoblje od najduže 90 dana.

\section{PROGJENA UČINKA NIŽIH GIJENA GORIVA NA DRŽAVNI PRORAČUN}

MPC benzina je 8. ožujka 20I5. iznosio 9,5I kunu, a dizela 9,oI kunu. U odnosu na prosjek MPC-a iz 2OI4., ove su cijene niže 9,8\% za benzinsko i 9,6\% za dizelsko gorivo - prosječna cijena Eurosupera 95 u 2014. iznosila je Io,5o kuna, a cijena Eurodiesela 9,87 kuna.

\section{Grafikon 4.}

Iznos PDV-a u ovisnosti o MPC-u (u kunama)

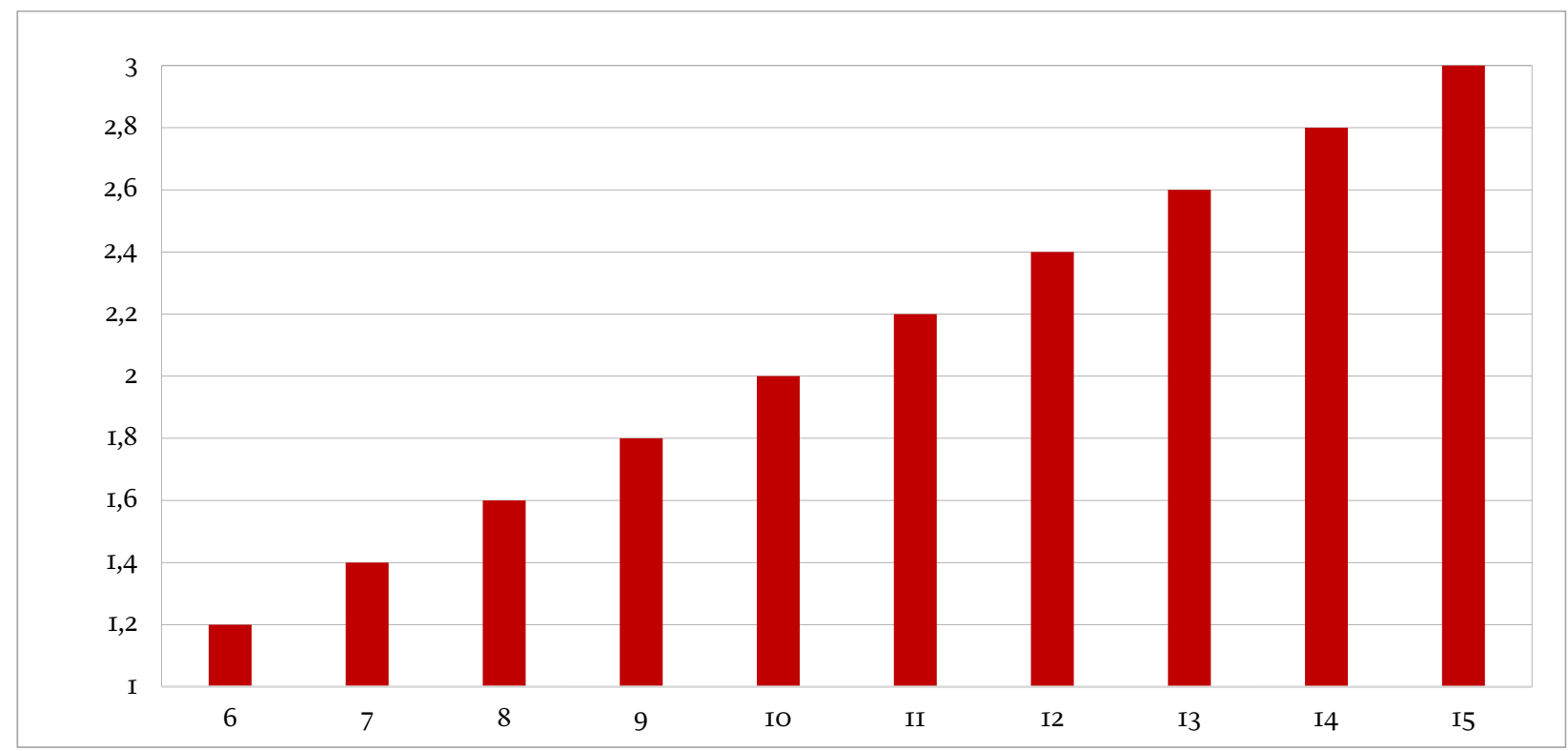

Izvor: Autori

Ključno je pitanje kako niže cijene naftnih derivata utječu na prihode državnog proračuna. Da bi se u potpunosti odgovorilo na ovo pitanje, valja podsjetiti da od nafte i naftnih derivata proračun ostvaruje dvije vrste prihoda: trošarine i PDV. Kao što pokazuje tablica I, iznos trošarina se određuje po litri (odnosno po I.ooo litara), pa je stoga u potpunosti neovisan o promjeni cijena nafte na tržištu, već ovisi isključivo o potrošnji nafte i naftnih derivata. Drugim riječima, za svaku litru goriva natočenog na benzinskoj crpki, država ubire točno određeni iznos trošarine (3,66 kune za benzinsko gorivo, tj. 2,86 kune za dizelsko gorivo), neovisno o tome je li MPC goriva 8, Io ili I2 kuna po litri. 
S druge strane, prihodi državnog proračuna od PDV-a značajno ovise o MPC-u goriva. Točno 20\% MPC-a čini PDV, pa kad pada MPC goriva padaju i prihodi od PDV-a i obratno. Grafikon 4 prikazuje iznos PDV-a u ovisnosti o MPC goriva.

Iz grafikona 4 je u potpunosti jasno da viši MPC litre goriva znači i viši prihod od PDV-a Međutim, sliku je potrebno pogledati iz šire perspektive, vodeći računa o barem trima stvarima: cjenovnoj elastičnosti potražnje, učinku redistribucije i vlastitih rashoda proračuna opće države.

\section{GJENOVNA ELASTIČNOST POTRAŽNJE}

Cijene su direktan i sveobuhvatan trošak korištenja dobra ili usluge. Cijena prijevoza tako može uključivati stvarni monetarni trošak (gorivo, održavanje), ali i nemonetarne troškove i koristi poput uštede vremena, komfora, rizika i slično ${ }^{13}$. Promjene cijena goriva stoga mogu utjecati na - primjerice učestalost putovanja, smjer, način, destinaciju, vrstu prijevoznoga sredstva, mjesto parkiranja itd. (Litman, 2013). Učinci promjene cijena na promjene ponašanja potrošača se uobičajeno mjere koeficijentom elastičnosti, definiranim sljedećom formulom:

$$
E_{D, P}=\frac{\frac{\Delta D}{D}}{\frac{\Delta P}{P}}=\frac{\text { relativna promjena potražnje }}{\text { relativna promjena cijene }}
$$

Koeficijent elastičnosti opisan gornjom formulom izražava za koliko se u relativnim terminima $\mathrm{u}$ postocima) mijenja potražnja za nekim dobrom ukoliko se cijena dobra promijeni za neki postotak. Npr. elastičnost od -O,I znači da povećanje cijene od Io\% smanjuje potražnju za I\% ${ }^{\text {I4 }}$. Cjenovna elastičnost potražnje u ovisnosti o cijeni je - barem teoretski - uvijek negativna, što znači da će uslijed pada cijene, potražnja za nekim dobrom uvijek porasti i obratno.

Litman (20I3) navodi rezultate brojnih studija prema kojima su kratkoročne elastičnosti potražnje za gorivom u odnosu na cijenu na razini od -o,25, dok su dugoročne nešto više, prosječno oko -o,6. To znači da je potražnja energenata zapravo neelastična te da promjena cijene dovodi do manje relativne promjene potražnje (npr. IO\%-tno smanjenje cijene goriva dovodi do rasta potražnje od 2,5\% u kratkom roku i 6\% na dugi rok). Jednostavnom se kalkulacijom može odrediti neto učinak na državni proračun (grafikon 5).

Izračunati neto učinak na državni proračun podrazumijeva direktan pad prihoda od PDV-a zbog pada MPC-a goriva te dodatne prihode od PDV-a i trošarina zbog rasta potrošnje ${ }^{15}$. Simulacija pokazuje da pad cijena goriva dovodi do kratkoročnog manjka prihoda proračuna prvenstveno zbog pada prihoda od PDV-a koji su ovisni o MPC-u. Pad cijena od Io\% (s Io na 9 kuna) implicira neto gubitak proračuna od 8 lipa po litri, pad od 20\% znači i6 lipa manje u proračunu po litri, a 30 postotni pad cijena znači 26 lipa manje ${ }^{16}$. Međutim, dugoročno se slika značajno mijenja pa tako pad cijena goriva od ıo\% u dugom roku dovodi do neto rasta prihoda proračuna od Io lipa po litri goriva, pad cijena od $20 \%$ znači I7 lipa više, a 30 postotni pad cijena dovodi do čak 22 lipa prihoda više u proračunu po litri.

\footnotetext{
${ }^{13}$ Nemonetarni troškovi i koristi označavaju one troškove, odnosno koristi, čija stvarna vrijednost nije izrečena u novčanim jedinicama. Primjerice, nemoguće je precizno odrediti koliko vrijedi ušteda vremena od jednoga sata ili manji rizik prometne nesreće i slično.

${ }^{14}$ Izračunato iz formule: -O,I-IO\%=-I\%.

${ }^{15}$ Primjerice, zamislimo da se uz stabilne cijene troši ıoo litara goriva. Uslijed pada cijene s ıo na 9 kuna (Io\%), država na Ioo litara uprihodi 20 kuna PDV-a manje. Međutim, pad cijena utječe na rast potražnje od 2,5\% u kratkom, odnosno $6 \%$ u dugom roku. To znači da se na potrošenih Ioo litara uz stabilne cijene, prilikom pada cijena od Io\% dodatno troši 2,5 litara u kratkom roku, tj. 6 litara u dugom roku. Na tu dodatnu potrošnju plaćaju se PDV od I,8 kuna po litri te trošarina od 3,I3 kuna po litri (ponderirani prosjek trošarine na bezolovni benzin i dizelsko gorivo, gdje bezolovni benzin sudjeluje s ponderom od jedne trećine, a dizel s dvije trećine). U kratkom roku država uprihodi dodatnih 4,5 kuna od PDV-a i 7,83 kuna od trošarina, što daje neto trošak od 7,68 kuna na Ioo litara $(-2 \mathrm{O}+4,5+7,83)$ ili 8 lipa po litri. U dugom roku, situacija je značajno povoljnija jer država uprihodi dodatnih Io,8 kuna od PDV-a i I8,78 kuna od trošarina, što daje neto korist od 9,58 kuna na Ioo litara $(-20+10,8+18,78)$ ili desetak lipa po litri.

I6 "Po litri goriva" zapravo uvijek u ovim simulacijama označava "po litri goriva" koje se troše u scenariju početnih cijena od ıo kn.
} 


\section{Grafikon 5.}

Simulacija neto troška/koristi za državni proračun, u ovisnosti o padu MPC-a (početna cijena Io kuna), u kunama po litri goriva potrošnje u scenariju stabilnih cijena

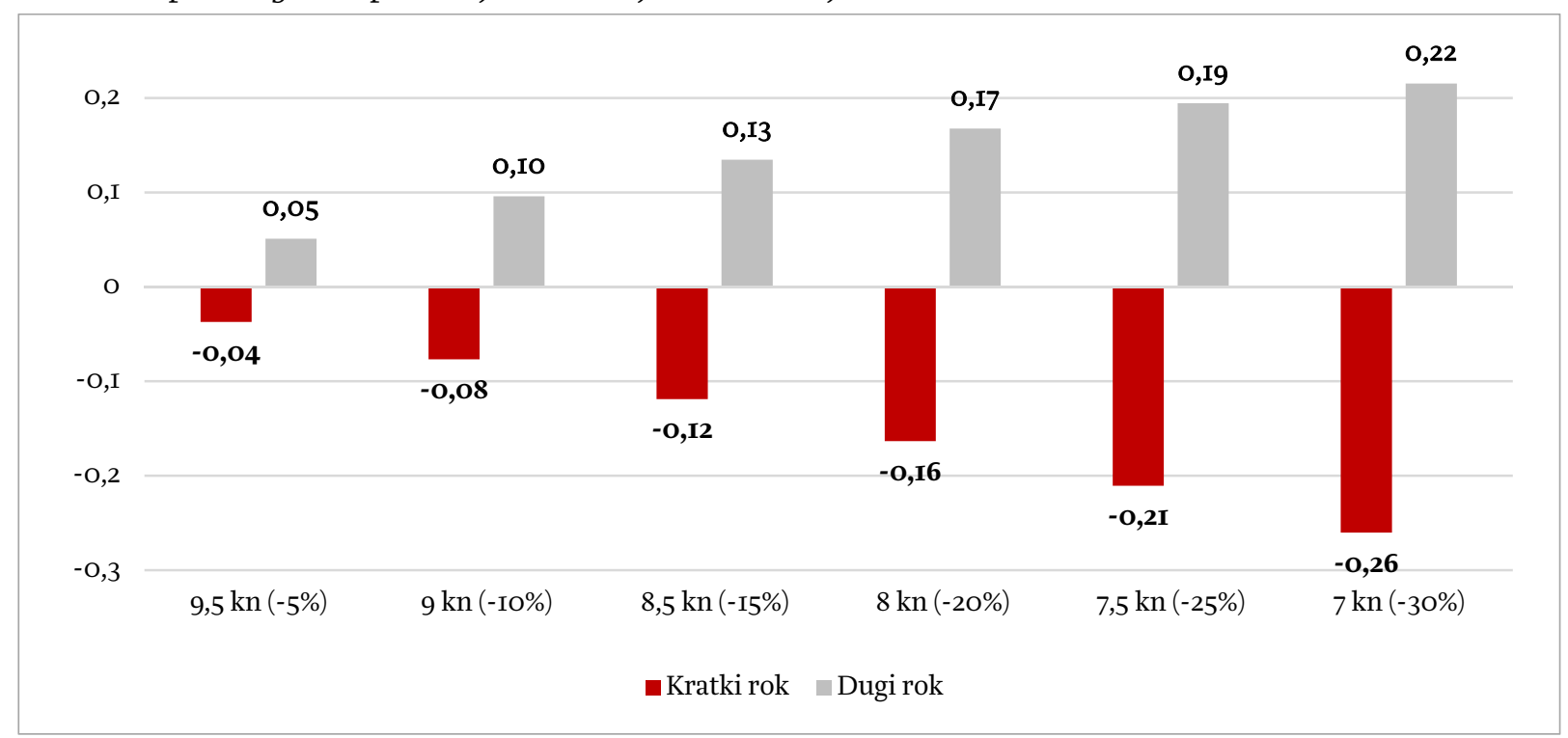

Izvor: Autori

Korištene procjene elastičnosti sukus su rezultata istraživanja za neka druga tržišta različita od hrvatskoga (SAD, Europa), a autorima nije poznato postoji li neko recentno istraživanje za hrvatsko tržište. Stoga ima smisla dvojiti o ispravnosti ovih rezultata koji značajno ovise o elastičnostima potražnje u ovisnosti o cijeni. Granični koeficijenti elastičnosti potražnje za naftnim derivatima u ovisnosti o MPC-a, koji bi trebali vrijediti da bi neto fiskalni učinak pada cijena bio neutralan (jednak nuli), su takvi koeficijenti kod kojih se pad prihoda od PDV-a zbog nižeg MPC-a goriva u potpunosti nadoknadi prihodima od trošarina i PDV-a uslijed povećane potražnje. Simulacije pokazuju da su granični koeficijenti elastičnosti za RH na razini od oko -0,4.

Osnovna je manjkavost ovih analiza što ne uključuju procjenu sekundarnih učinaka, poput rasta dobiti naftnih kompanija zbog povećane prodaje, rasta dobiti poduzeća koja opskrbljuju distribucijsku mrežu uslijed manjeg troška poslovanja, ali i pada dobiti prijevoznika zbog supstitucije javnoga prijevoza (vlak, tramvaj, autobus) vlastitim (autom) i slično ${ }^{\mathrm{T}}$.

\section{UČINAK REDISTRIBUCIJE}

Polazeći od pretpostavke da svi pojedinci barataju s određenim dohotkom kojeg troše na razna dobra i usluge, učinak redistribucije je bitna odrednica koju valja imati na umu prilikom razmatranja nižih prihoda od PDV-a zbog pada cijene goriva. Naime, ukoliko pojedinac zbog niže cijene mjesečno na gorivo troši Ioo kuna manje nego ranije, taj će iznos potrošiti na neka druga dobra i usluge na što će također platiti PDV, najvjerojatnije također po općoj stopi ${ }^{18}$. Može se zaključiti da snižavanje cijena goriva $u$ najvećoj mjeri dovodi samo do redistribucije prihoda od PDV-a. Ako i dođe do smanjenja prihoda od PDV-a zbog potrošnje dobara ili usluga na koje se primjenjuje snižena stopa, tada je to smanjenje zanemarivo malo.

\footnotetext{
${ }^{17}$ Uz pretpostavku da se smanjenje cijena ne odražava na niže cijene proizvoda, što obično nije slučaj.

${ }^{18}$ Premda postoje i snižene stope PDV-a, one se primjenjuju na osnovna dobra poput kruha, mlijeka, dječje hrane itd. za koja se pretpostavlja da se troše u istim količinama, bez obzira na povećanje ili smanjenje raspoloživa dohotka.
} 


\section{VLASTITI RASHODI PRORAČUNA OPĆE DRŽAVE}

Imajući u vidu da je i javni sektor jedan od potrošača nafte i naftnih derivata, niže cijene goriva pogoduju snižavanju rashodne strane proračuna. Za svaku kunu niže cijene goriva neto učinak za javni sektor je pozitivan i iznosi 8o lipa, jer se uz pretpostavku nepromijenjene potrošnje goriva u javnom sektoru snižavaju rashodi iz proračuna za točno I kunu (cijena goriva niža je za jednu kunu), a istovremeno se evidentira tek manji prihod od PDV-a od 20 lipa.

Ukupnu neto korist za javni sektor nije moguće adekvatno procijeniti jer podaci o ukupnoj potrošnji naftnih derivata javnog sektora nisu javno dostupni. Naime, najdetaljniji prikaz rashoda državnog i lokalnih proračuna te izvanproračunskih fondova je na razini odjeljka (odjeljak 3223 energija), koji osim rashoda za motorni benzin i dizel gorivo (osnovni račun 32234), uključuje i rashode za električnu energiju, toplu vodu (toplana), plin te ostale materijale za proizvodnju energije (ugljen, drva, teško ulje itd.).

Iz navedenih obrazloženja može se zaključiti da niži MPC goriva ne bi trebao imati značajnije negativne učinke na proračun jer bi se izgubljeni prihodi od PDV-a nadoknadili povećanom potrošnjom, redistribucijom prihoda od PDV-a te nižim troškovima javnog sektora za motorni benzin i dizel gorivo.

\section{GIJENE GORIVA I TROŠARINE U EU-U}

Prosječna cijena benzina svih članica EU-a iznosila je početkom 20I5. I,22 eura, no cijene značajno variraju po zemljama. Primjerice, I4. siječnja 2015. cijena benzina bila je najniža u Poljskoj (o,93 eura), a najviša u Nizozemskoj (I,56 eura), odnosno čak 67\% više nego u Poljskoj; MPC u Hrvatskoj (I,I2 eura) nešto je niži od prosjeka EU-a ${ }^{19}$.

Istoga je dana prosječna cijena dizela u EU-u iznosila I,I6 eura. Najniža je zabilježena u Poljskoj (o,95 eura), a najviša u Velikoj Britaniji (I,49 eura). Kod dizela je razlika između najviše i najniže cijene nešto niža u odnosu na benzin (cijena u Velikoj Britaniji je 56\% viša nego u Poljskoj). U RH je iznosila I,O7 eura, što je opet nešto niže od prosjeka EU-a.

Cijene motornih goriva razlikuju se prvenstveno zbog primjene različitih stopa trošarina i PDV-a. Postoji tek Direktiva 2003/96/EC kojom se uređuju isključivo minimalne trošarine - 359 eura na 1.ooo litara za benzin i 330 eura na I.ooo litara za dizelska goriva. Stoga su evidentne brojne razlike među članicama EU-a u primjeni stopa trošarina. S obzirom da se na cijenu motornih goriva plaća PDV po standardnoj stopi, dio razlika dolazi i od primjene različitih stopa PDV-a. Neke zemlje primjenjuju i dodatne poreze kojima destimuliraju potrošnju fosilnih goriva. Navedene različite politike oporezivanja dovode do različitih razina cijena motornih goriva. Na grafikonima 6 i 7 prikazane su strukture cijene benzina i dizela po članicama EU-a te udio poreza u MPC-u goriva.

\footnotetext{
19 Ukoliko se cijene benzina stavi u omjer sa životnim standardom građana, tj. podijele se s BDP-om po stanovniku (u eurima) po standardu kupovne moći (Eurostat, 20I5), dobiva se izračunata realna cijena benzina. Realne cijene su očekivano značajno nepovoljnije u zemljama s relativno nižim standardom od prosjeka EU-a. Tako je realna cijena benzina najviša u Bugarskoj, Rumunjskoj te RH. Primjerice, realna cijena benzina u RH je otprilike dvostruko viša nego u Austriji, a 20\% viša nego u susjednoj Sloveniji.
} 


\section{Grafikon 6.}

Usporedba strukture cijene motornog benzina u članicama EU-a (u eurima, lijeva skala) te udio trošarine i PDV-a* u MPC-u benzina (u \%, desna skala), stanje I4. siječnja 2015.

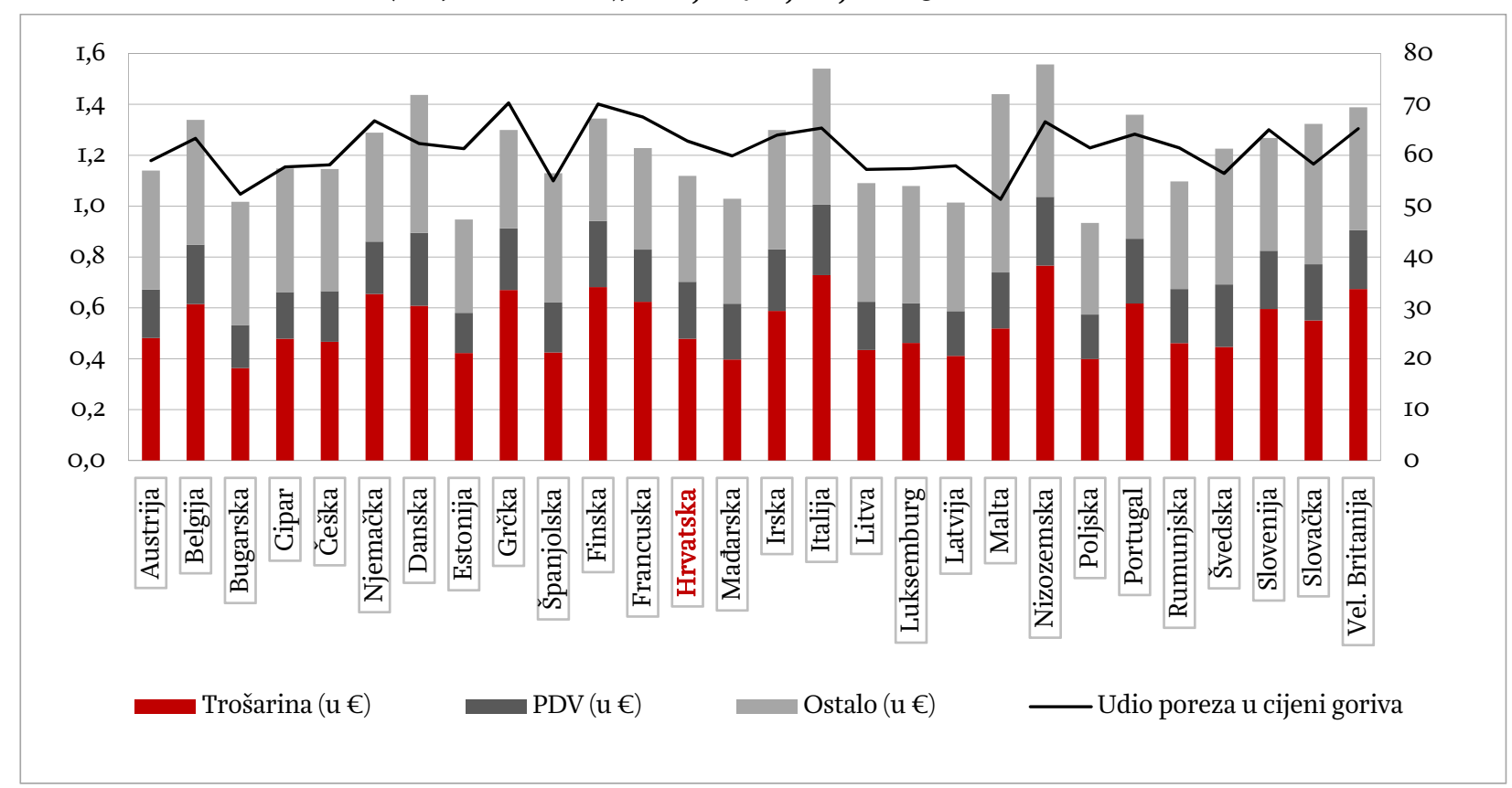

*Iznos trošarine i stopa PDV-a važeća I. siječnja 2015.

Izvor: Fuel Prices Europe Info (2015); European Commission (2015); izračun autora

\section{Grafikon 7.}

Usporedba strukture cijene dizela u članicama EU-a (u eurima, lijeva skala) te udio trošarine i PDV-a* u MPC-u dizela ( $\%$, desna skala), stanje I4. siječnja 2015.

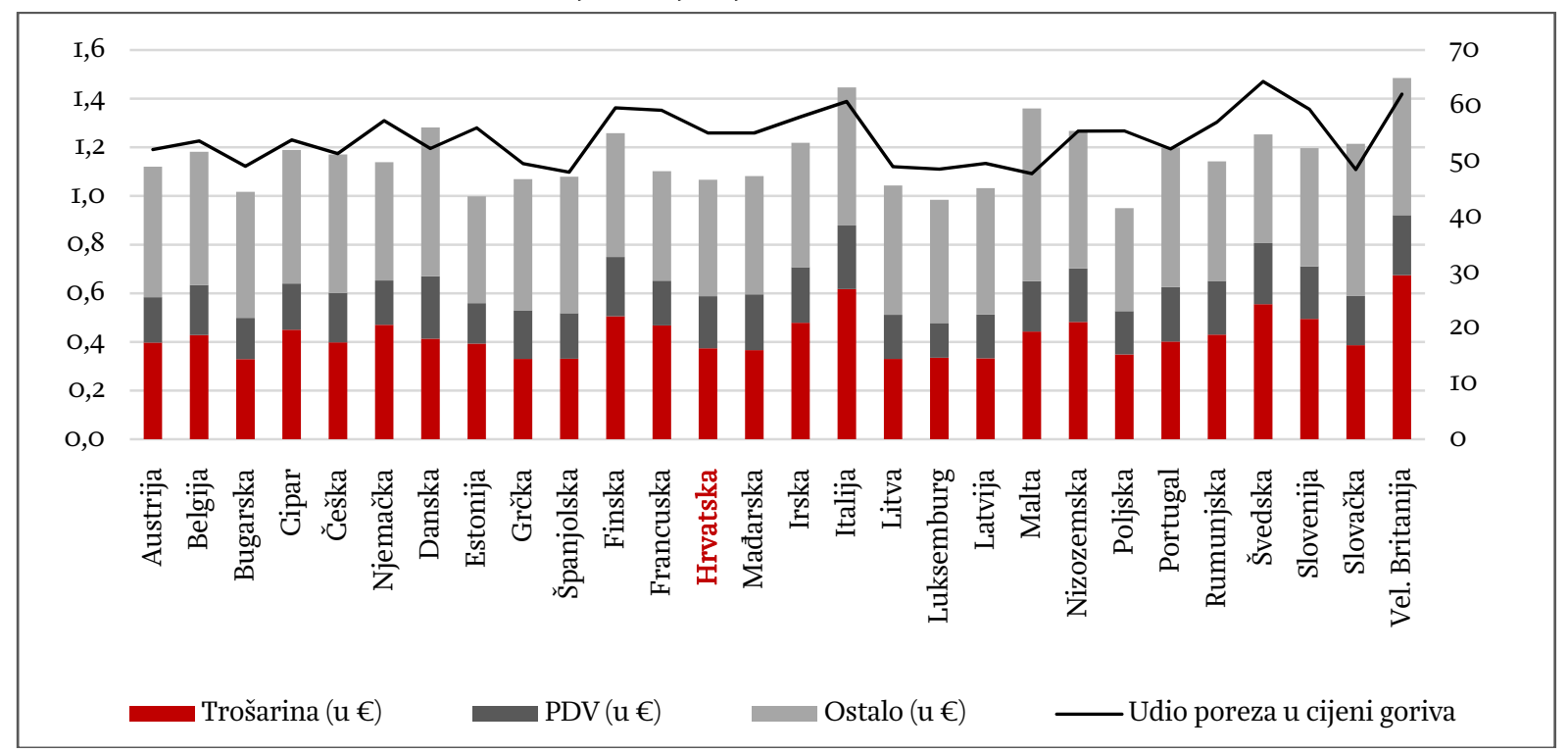

*Iznos trošarine i stopa PDV-a važeća I. siječnja 2015.

Izvor: Fuel Prices Europe Info (2015); European Commission (2015); izračun autora

Od I,22 eura prosječnog MPG-a litre benzina u članicama EU-a, u prosjeku 43,6\% MPC-a čini trošarina, a I7,7\% PDV. Prema tome, u MPC-u goriva u EU-u u prosjeku 6I,4\% se odnosi na poreze koji se slijevaju u državne proračune. U RH je udio poreza u MPG-u benzina tek neznatno viši od prosjeka EU-a i čini otprilike $62,8 \%$. Premda je udio trošarina u cijeni u RH čak nešto ispod prosjeka EU-a, viši udio poreza u MPC-u benzina proizlazi iz relativno više stope PDV-a (25\% u odnosu na 2I,6\% u prosjeku EU-a). Najviše udjele poreza u MPC-u benzina imaju Grčka (70,3\%) i Finska (70\%), a najniže Malta (51,3\%) i Bugarska $(52,4 \%)$. 
Prosječan MPC litre dizela u zemljama EU-a iznosi I,I6 eura, a 36,6\% u prosjeku čini trošarina (o,43 eura). Jednako kao i kod benzina, 17,7\% MPC-a je u prosjeku PDV (o,21 eura). Prema tome, u MPC-u dizela u EUu u prosjeku 54,3\% cijene odlazi na porez kojim se pune državni proračuni. RH je i ovdje otprilike na razini prosjeka EU-a (55,I\%). Najviše udjele poreza u MPC-u dizela imaju Švedska (64,3\%) i Velika Britanija (62,1\%), a najniže Malta (47,8\%) i Španjolska (48\%).

Usporedna analiza pokazuje da je cijena goriva u RH nešto niža od prosjeka zemalja EU-a. Po svakoj litri benzina u hrvatski proračun (od trošarina i PDV-a) odlazi 39 lipa manje u odnosu na prosjek svih zemalja EU-a, odnosno 35 lipa manje po svakoj litri dizela. No realna cijena goriva hrvatskim je građanima relativno skuplja u odnosu na građane ostalih članica EU-a prvenstveno zbog nižeg životnog standarda i visoke stope PDV-a.

U svemu tome postoji još jedna dimenzija koja je posljednjih godina itekako bitna i kojoj također valja posvetiti nekoliko odjeljaka u ovome radu. Radi se o učinkovitom trošenju energetskih resursa. Povećanje energetske učinkovitosti među ključnim je ciljevima europskih razvojnih strategija (Europa $202 \mathrm{O}^{20} \mathrm{i}$ Energija 2020 ${ }^{21}$ i mjerama za prelazak na konkurentno niskougljično gospodarstvo do 205O. Klimatske i energetske strategije za razdoblje do 2020., poznatije su pod imenom "2O-2O-20", a na razini EU-a postavljaju tri ključna cilja za 2020. a to je $20 \%$-tno:

- smanjenje emisije stakleničkih plinova u odnosu na razine iz 199o.;

- rast udjela potrošnje energije iz obnovljivih izvora;

- poboljšanje energetske učinkovitosti.

Postizanje ciljeva povećanja energetske učinkovitosti na razini EU-a moguće je isključivo uz adekvatan doprinos svih članica EU-a, zbog čega je zakonodavni okvir EU-a obvezujući za sve članice. Pristupanjem EU-u, RH se obvezala primijeniti i njenu pravnu stečevinu te preuzeti obvezu ostvarivanja ciljeva povećanja energetske učinkovitosti do 2020.

U ukupnoj neposrednoj potrošnji energije i emisiji CO2 u RH, promet sudjeluje s oko 30\%, a gotovo se 90\% od toga odnosi na cestovni promet (IRMO, 2013). Valjalo bi ispitati može li, i u kojoj mjeri, oporezivanje energenata putem trošarina doprinijeti stabilizaciji cijena i promoviranju učinkovitog korištenja energetskih resursa. U izvješću Europskog Parlamenta (20I4) definirano je nekoliko smjernica kojima bi vlasti mogle minimizirati učinak promjene cijena nafte na cijene energenata:

- Izbjegavati smanjivanje poreza/trošarina na energente pri povećanju cijena nafte. Kratkoročni mehanizmi smanjivanja poreza se mogu primijeniti, ali isključivo usmjereni na kućanstva nižeg dohotka.

- Odrediti poreznu stopu koja će poticati nižu potražnju za naftnim derivatima.

- Poticati korištenje alternativnih goriva u transportu radi dodatnog smanjivanja potražnje za fosilnim gorivima.

\section{ZAKLJUČAK}

Cijene sirove nafte na svjetskom tržištu u drugoj polovici 20I4. zabilježile su značajan pad, što je dovelo i do pada MPC-a goriva i na hrvatskom tržištu. Zemlje uvoznice nafte, u koje spada i RH, mogle bi značajno profitirati od pada cijena nafte. Predviđanja pokazuju da bi hrvatski BDP u 2015. zbog relativno niske cijene nafte mogao biti viši za o,4-o,8\%. Nižim cijenama goriva posebno se raduju građani, budući da je prosječan spremnik goriva pojeftinio za 50-ak kuna u odnosu na sredinu 2014.

\footnotetext{
${ }^{20}$ Europa 2020 je strategija gospodarskog rasta EU-a za razdoblje do 2020. s ciljem razvoja pametnog, održivog i uključivog gospodarstva koje će omogućiti visoke razine zaposlenosti, produktivnosti i socijalne kohezije.

${ }^{2 I}$ Energija 2020 strategija je Europske komisije (2OIO) koja postavlja ciljeve konkurentne, održive i sigurne energije te definira prioritete koji uključuju uštede energije, razvoj tržišta s konkurentnim cijenama i sigurnom opskrbom, razvoj tehnologija i pregovore sa zemljama izvoznicama.
} 
Međutim, padu cijena goriva ne vesele se baš svi. Glavni cilj ovoga rada bila je analiza utjecaja kretanja cijena goriva na prihode državnog proračuna koji se smatra najvećim gubitnikom. Na svaku se litru goriva plaćaju dvije vrste poreznih nameta - trošarina i PDV. Premda pad cijena goriva neće utjecati na prihode od trošarina na benzin i dizel, jer su one fiksne i obračunavaju se po litri, svakako će utjecati na pad prihoda od PDV-a. Međutim, analiza provedena u ovome radu pokazuje da dugoročan učinak pada cijena goriva na prihode državnog proračuna ne bi trebao biti negativan, jer:

- niža cijena dovodi do veće potrošnje;

- dio raspoloživa dohotka se - umjesto za gorivo - troši na neka druga dobra i usluge;

- niži su državni prihodi od PDV-a, ali ujedno su niži i rashodi za trošak goriva, pri čemu je neto učinak pozitivan.

Usporedna analiza pokazuje da je cijena goriva u RH nešto niža od prosjeka zemalja EU-a. Po svakoj litri benzina $u$ hrvatski proračun (od trošarina i PDV-a) odlazi 39 lipa manje u odnosu na prosjek svih zemalja EU-a, odnosno 35 lipa manje po svakoj litri dizela. No realna je cijena goriva hrvatskim građanima relativno skuplja nego građanima ostalih članica EU-a, prvenstveno zbog nižeg životnog standarda i visoke stope PDV-a. Eventualno dodatno povisivanje trošarina moglo bi biti potrebno i opravdano u slučaju da prijedlog monetizacije HAC-a ne bude prihvaćen (što je vrlo izgledno obzirom na negativnu percepciju javnosti), a ostvareni prihodi bi se mogli namjenski trošiti za financiranje budućih dospijeća obveza HAC-a.

Povećanje energetske učinkovitosti među ključnim je ciljevima europskih razvojnih strategija, a u ukupnoj neposrednoj potrošnji energije i emisiji CO2 u RH, promet sudjeluje s oko 30\%. Prema tome, u sektoru prometa postoji ogroman potencijal za učinkovitije trošenje energetskih resursa. Postupni prelazak na energetski učinkovitije društvo dugoročan je proces, a valjalo bi dodatno ispitati može li se to postići kombinacijom poticaja za potrošnju alternativnih goriva i postupnim demotiviranjem potrošnje fosilnih goriva višim trošarinama.

\section{LITERATURA}

Bajo, A. i Petrušić, J., 20I4. Državna jamstva i financijske obveze javnih trgovačkih društava iz cestovnog prometa. Newsletter, br. 92.

Baker Hughes, 20I5. Baker Hughes U.S. Rig Count - Year to Year Comparisons.[I6.2.2OI5.]

Businessinsider, 20I4. UBS: Here's What A \$io Move In Oil Does To GDP Around The World. [9.I2.2OI4. ]

Cijene goriva info, 2015. Cijene goriva.

Council Directive 2003/96/EC of 27 October 2003 restructuring the Community framework for the taxation of energy products and electricity. Bruxelles: European Commission.

EIA, 20I5a. Europe Brent Spot Price. [3.I.2OI5.]

EIA, 20I5b. U.S. Field Production of Crude Oil. [ 3.I.2OI5.]

European Commission, 20IO. Communication "Energy 2020 - A strategy for competitive, sustainable and secure energy". Brussels: European Commission.

European Commission, 20I5. Excise Duty Tables Part II - Energy Products and Electricity. [I6.2. 20I5.]

European Parliament, 20I4. The Impact of the Oil Price on EU Energy Prices. Directorate General for Internal Policies - Policy Department A: Economic and Scientific Policy.

Eurostat, 20I5. GDP and main components - Current prices.

Fortune, 2015. The world's biggest winners and losers from cheap oil, in one chart [7.I.2OI5.]

Fuel Prices Europe Info, 2OI5. Fuel prices in Europe by January I4, 2OI5. [I4.I.2OI5.]

IRMO, 2OI3. Ekološka i ekonomska analiza izvedivosti uvođenja poreznog sustava na osobna motorna vozila u Hrvatskoj zavisna o emisiji CO2 i Euro normama o emisijama štetnih plinova. Zagreb: Institut za razvoj i međunarodne odnose. 
Litman, T. A., 20I3. Understanding Transport Demands and Elasticities - How Prices and Other Factors Affect Travel Behavior. Victoria Transport Policy Institute.

Ministarstvo financija, 2015. Vremenske serije podataka - državni proračun. [18.2.2015.]

Ministarstvo gospodarstva, 20I5. Cijene energenata [3.I.2OI5.]

Newbery, D. M., 2005. Why Tax Energy? Towards a More Rational Policy. The Energy Journal,

Poslovni dnevnik, 20I5. Izjave kuvajtskog ministra stabilizirale cijene nafte nadomak 6I dolar. [I6.2.2OI5.]

Pravilnik o utvrđivanju najviših maloprodajnih cijena naftnih derivata, NN I45/I2. Zagreb: Narodne novine.

Uredba o visinama trošarina na motorne benzine i plinsko ulje, NN 28/II. Zagreb: Narodne novine.

Uredba o visini posebnog poreza na naftne derivate, NN 44/o7. Zagreb: Narodne novine.

Uredba o visini trošarine na motorne benzine, plinsko ulje i kerozin za pogon, NN 137/I2., 93/13., I09/13., 48/I4. Zagreb: Narodne novine.

Uredba o visini trošarine za bezolovni motorni benzin, NN IO2/IO. Zagreb: Narodne novine.

Vorša, B., 20I2. Svako malo domaće nalazište nafte za nas je veliko. [3.I.2OI5.]

Vox, 20I4. Why oil prices keep falling. [9.12.2OI4.]

Zakon o cestama, NN 84/II., 22/I3., 54/I3., I48/I3., 92/I4. Zagreb: Narodne novine.

Zakon o posebnom porezu na naftne derivate, NN 5I/94., 67/99., 55/OO., IOI/Oo., 27/OI., IO7/OI., I23/O3., 57/o6. Zagreb: Narodne novine.

Zakon o trošarinama, NN 22/I3., 32/I3., 8I/I3. Zagreb: Narodne novine.

Zakon o tržištu nafte i naftnih derivata NN 68/OI., 57/O6., I8/II., I44/I2., I9/I4. Zagreb: Narodne novine. Zakon o željeznici, NN 94/13., I48/13. Zagreb: Narodne novine. 